ORIGINAL ARTICLE

\title{
Does carbon dioxide retention during exercise predict a more rapid decline in $\mathrm{FEV}_{1}$ in cystic fibrosis?
}

\author{
S M Javadpour, H Selvadurai, D L Wilkes, J Schneiderman-Walker, A L Coates
}

Arch Dis Child 2005;90:792-795. doi: 10.1136/adc.2004.070110

See end of article for authors' affiliations ......................

Correspondence to: Dr H C Selvadurai, Department of Respiratory Medicine, The Hospital for Sick Children, Toronto, Ontario M5G1X8,

Canada;

hiran.selvadurai@ sickkids.ca

Accepted 5 April 2005
Background: Carbon dioxide $\left(\mathrm{CO}_{2}\right)$ retention during exercise is uncommon in mild to moderate lung disease in cystic fibrosis (CF). The ability to deal with increased $\mathrm{CO}_{2}$ is dependent on the degree of airflow limitation and inherent $\mathrm{CO}_{2}$ sensitivity. $\mathrm{CO}_{2}$ retention $\left(\mathrm{CO}_{2} \mathrm{R}\right)$ can be defined as a rise in $\mathrm{P}_{\mathrm{ET}} \mathrm{CO}_{2}$ tension of $\geqslant 5 \mathrm{~mm} \mathrm{Hg}$ with exercise together with a failure to reduce $\mathrm{P}_{\mathrm{ET}} \mathrm{CO}_{2}$ tension after peak work by at least $3 \mathrm{~mm} \mathrm{Hg}$ by the termination of exercise.

Aim: To ascertain if carbon dioxide retention during exercise is associated with more rapid decline in lung function.

Methods: Annual spirometric and exercise data from 58 children aged 11-15 years, with moderate CF lung disease between 1996 and 2002 were analysed.

Results: The mean $\mathrm{FEV}_{1}$ at baseline for the two groups was similar; the $\mathrm{CO}_{2} \mathrm{R}$ group $(\mathrm{n}=15)$ was $62 \%$ and the non- $\mathrm{CO}_{2}$ retention group $\left(\mathrm{CO}_{2} \mathrm{NR}\right)$ was $64 \%(\mathrm{n}=43)$. The decline in $\mathrm{FEV}$ after 12 months was $-3.2 \%$ (SD 1.1) in the $\mathrm{CO}_{2} \mathrm{R}$ group and $-2.3 \%$ (SD 0.9) in the $\mathrm{CO}_{2} \mathrm{NR}$ group. The decline after 24 months was $-6.3 \%$ (SD 1.3) and $-1.8 \%$ (SD 1.1) respectively. After 36 months, the decline in $\mathrm{FEV}_{1}$ was $-5.3 \%$ (SD 1.2 ) and $-2.6 \%$ (SD 1.1) respectively. The overall decline in lung function was $14.8 \%$ (SD 2.1 ) in the $\mathrm{CO}_{2} \mathrm{R}$ group and $6.7 \%$ (SD 1.8) in the $\mathrm{CO}_{2} \mathrm{NR}$ group. Using the primary outcome measure as a decline in $\mathrm{FEV}_{1}$ of $>9 \%$, final multivariate analysis showed that the relative risks for this model were $195 \% \mathrm{Cls}$ in parentheses): $\Delta \mathrm{P}_{\mathrm{ET}} \mathrm{CO}_{2} 11.61$ (3.41 to 24.12$)$, peak $\dot{\mathrm{V}} \mathrm{O}_{2} 1.23$ (1.10 to 1.43 ), and initial $F E V_{1} 1.14$ (1.02 to 1.28$)$.

Conclusion: Results show that the inability to defend carbon dioxide during exercise is associated with a more rapid decline in lung function.

\section{C} ystic fibrosis (CF) is a multisystem condition with the greatest morbidity and mortality arising from the pulmonary component of the disease. Though the overall survival of the condition has improved markedly over the past two decades, the natural history of the disease continues to be characterised by a steady decline in lung function. Pulmonary function testing provides a more objective assessment of the progress of pulmonary disease in CF than do clinical scoring systems. ${ }^{1-3}$ Forced expiratory volume in one second $\left(\mathrm{FEV}_{1}\right)$ has been shown to be closely linked to mortality. ${ }^{4}$ Other factors that play a major role in the decline of lung function are infections due to Pseudomonas aeruginosa and Burkholderia cepacia, ${ }^{5}$ nutritional status, ${ }^{6}$ and gender. ${ }^{1}$ In view of this, markers to identify children who may be at a higher risk of a more rapid decline than others are continually being sought. Identification of such markers may allow earlier intervention with more aggressive therapy and alert clinicians to their more at risk population. Previous studies have evaluated the prognostic value of exercise testing in patients with cystic fibrosis, ${ }^{78}$ and patients with high levels of aerobic fitness showed a three times greater likelihood of survival than patients with lower levels of fitness. $^{7}$

Carbon dioxide retention during exercise is uncommon in mild to moderate CF lung disease. The ability to deal with increased carbon dioxide is dependent on the degree of airflow obstruction and the inherent sensitivity to carbon dioxide. Patients with an $\mathrm{FEV}_{1}$ less than $60 \%$ are more likely to retain $\mathrm{CO}_{2}{ }^{9}$ We sought to ascertain if carbon dioxide retention during exercise is associated with a greater rate of decline in $\mathrm{FEV}_{1}$. We hypothesised that $\mathrm{CO}_{2}$ retention during exercise could be a measure that predicts children who are at higher risk of decline in $\mathrm{FEV}_{1}$. This is because $\mathrm{CO}_{2}$ retention is a marker of mechanical impairment, increased dead space, ventilation perfusion abnormalities, and the patient's response to $\mathrm{CO}_{2}$ stimulus may not be detectable on routine pulmonary function testing.

\section{METHODS}

\section{Subjects}

As part of the annual evaluation of children with CF, an aerobic exercise test and pulmonary function tests are performed. This was a retrospective analysis of exercise and pulmonary function data in children with CF. The inclusion criteria for this study were children with CF who had a minimum of three consecutive years of exercise test data. The recruitment period for this study was 1996 to 2000. This ensured that there was a minimum of three consecutive years of follow up. The exercise test data were excluded from analysis if the children had an acute pulmonary exacerbation as defined by an acute $>10 \%$ decrease in $\mathrm{FEV}_{1}$, increased productive cough, and/or pyrexia at the time of the exercise test. Children who had Burkholderia cepacia or proven cystic fibrosis related diabetes were excluded from the study.

\section{Pulmonary function tests}

FVC, $\mathrm{FEV}_{1}$, and MVV (Gould Sentry System 50, Gould Inc. Dayton, Ohio) were measured annually according to standard spirometric techniques. ${ }^{10}$ Pulmonary function values were

Abbreviations: $\mathrm{CO}_{2}$, carbon dioxide; $\mathrm{CO}_{2} \mathrm{R}, \mathrm{CO}_{2}$ retention; $\mathrm{CO}_{2} \mathrm{NR}$, $\mathrm{CO}_{2}$ non-retention; $\mathrm{FVC}$, forced vital capacity; $\mathrm{FEV}_{1}$, forced expiratory volume in one second; $\mathrm{MVV}$, maximal voluntary ventilation; $\mathrm{PaCO}_{2}$, arterial partial pressure $\mathrm{CO}_{2} ; \mathrm{P}_{\mathrm{ET}} \mathrm{CO}_{2}$, end-tidal $\mathrm{CO}_{2}$ partial pressure; $\mathrm{SD}$, standard deviation; $\dot{\mathrm{V}}_{\mathrm{E}}$, minute ventilation, $\dot{\mathrm{V}}_{2}, \mathrm{CO}_{2}$ production; $\mathrm{VO}_{2}$, oxygen consumption 
Table 1 Baseline demographics and exercise parameters carbon dioxide retainers $\left(\mathrm{CO}_{2} \mathrm{R}\right)$ versus nonretainers $\left(\mathrm{CO}_{2} \mathrm{NR}\right)$

\begin{tabular}{lll}
\hline & $\mathrm{CO}_{2} \mathrm{R}(\mathrm{n}=15)$ & $\mathrm{CO}_{2} \mathrm{NR}(\mathrm{n}=43)$ \\
\hline Age (years) & $13.9(1.7)$ & $13.6(1.8)$ \\
Male:female ratio & $6: 9$ & $16: 27$ \\
Body mass index $\left(\mathrm{kg} / \mathrm{m}^{2}\right)$ & $21.2(0.7)$ & $21.9(0.8)$ \\
$\mathrm{PS}: \mathrm{Pl}$ ratio & $0: 15$ & $1: 42$ \\
Baseline peak $\mathrm{VO}_{2}(\mathrm{ml} / \mathrm{kg} / \mathrm{min})$ & $36.8(3.1)$ & $37.3(3.4)$ \\
Baseline $\mathrm{FEV}(\%$ predicted) & $62(4)$ & $65(4)$ \\
$\mathrm{RQ}$ (at peak exercise) & $1.17(0.1)$ & $1.15(0.1)$ \\
$\%$ increase in tidal volume & $45.7(2.2)$ & $95.4(2.8)$ \\
\hline
\end{tabular}

$\mathrm{PS}$, pancreatic sufficiency; $\mathrm{Pl}$, pancreatic insufficiency; $\mathrm{FEV}_{1}$, forced expiratory volume in 1 second; $R Q$, respiratory quotient.

expressed as a percent of predicted value based on standards previously developed in this laboratory. ${ }^{11} \mathrm{MVV}$ was assessed by the sprint method. ${ }^{12}$

\section{Exercise testing}

Patients performed an annual maximal incremental cycling test on an electrically braked cycle ergometer (Rodby Electronik AB, Enhorna, Sweden). One minute work increments were chosen according to sex, height, and physical activity level. ${ }^{13}$ Heart rate (lead II, ECG), inspired $\dot{\mathrm{V}}_{\mathrm{E}}$ (Parkinson-Cowan dry gas meter, Manchester, UK), mixed expired oxygen (Applied Electrochemistry oxygen analyser, Sunnyvale CA), carbon dioxide (P.K.Morgan 901-MK2, Chatham, UK), and respiratory rate (thermister) were monitored continuously on an eight channel recorder. $\dot{\mathrm{VO}}_{2}$, and $\dot{\mathrm{V}} \mathrm{CO}_{2}$ were calculated using the nitrogen balance technique. ${ }^{14}$ The test was considered complete when the patient reached exhaustion, based on an inability to maintain a continuous pedalling speed of 60 revolutions per minute. At the 15 second mark of each work rate, the end-tidal $\mathrm{PCO}_{2}$ $\left(\mathrm{P}_{\mathrm{ET}} \mathrm{CO}_{2}, \mathrm{~mm} \mathrm{Hg}\right)$ was calculated by measuring the expired carbon dioxide at the mouthpiece at the end of tidal breathing. The peak and end of exercise $\mathrm{P}_{\mathrm{ET}} \mathrm{CO}_{2}$ were recorded.

\section{Data analysis}

The children were divided into those who retained $\mathrm{CO}_{2}$ during progressive exercise test $\left(\mathrm{CO}_{2} \mathrm{R}\right.$ group $)$ and those who did not $\left(\mathrm{CO}_{2} \mathrm{NR}\right.$ group). $\mathrm{CO}_{2}$ retention was arbitrarily defined as a rise of $\geqslant 5 \mathrm{~mm} \mathrm{Hg} \mathrm{P}_{\mathrm{ET}} \mathrm{CO}_{2}$ from the first work rate until the peak work rate and a failure to reduce $\mathrm{P}_{\mathrm{ET}} \mathrm{CO}_{2}$ after the peak work rate by $3 \mathrm{~mm} \mathrm{Hg}$ by the termination of the exercise.

The Shapiro Wilk statistic was used to assess if the data followed a normal distribution. One way ANOVA with repeated measures was used to detect the changes in $\mathrm{FEV}_{1}$

Table 2 Univariate analysis for decline in $\mathrm{FEV}_{1}$ over 36 months $>9 \%$

\begin{tabular}{llll}
\hline Parameter & $\begin{array}{l}\text { Relative } \\
\text { risk }\end{array}$ & p value & $\begin{array}{l}\mathbf{9 5 \%} \mathrm{Cl} \text { for risk } \\
\text { ratio }\end{array}$ \\
\hline Age (years) & 1.00 & 0.78 & 0.98 to 1.08 \\
Female & 1.23 & 0.41 & 0.37 to 1.78 \\
$\mathrm{BMl}\left(\mathrm{kg} / \mathrm{m}^{2}\right)$ & 0.96 & 0.61 & 0.43 to 1.14 \\
$\dot{\mathrm{V}} \mathrm{O}_{2}$ peak $(\mathrm{ml} / \mathrm{kg} / \mathrm{min})$ & 0.78 & 0.16 & 0.51 to 0.92 \\
$\dot{\mathrm{V}}_{\mathrm{E} \text { peak }(\mathrm{l} / \mathrm{min})}$ & 0.85 & 0.28 & 0.66 to 0.96 \\
$\mathrm{FEV}_{1}$ at start $(\%)$ & 0.92 & 0.18 & 0.81 to 1.05 \\
$\Delta \mathrm{P}_{\mathrm{ET}} \mathrm{CO}_{2}{ }^{*}(\mathrm{~mm} \mathrm{Hg})$ & 5.81 & 0.0005 & 4.20 to 7.18 \\
\hline
\end{tabular}

$\mathrm{BMI}$, body mass index; $\dot{\mathrm{V}}_{2}$, oxygen consumption; $\dot{\mathrm{V}}_{\mathrm{E}}$, minute ventilation $\triangle \mathrm{P}_{\mathrm{ET}} \mathrm{CO}_{2}$, [(change in $\mathrm{P}_{\mathrm{ET}} \mathrm{CO}_{2}$ to peak exercise) + (change in $\mathrm{P}_{\mathrm{ET}} \mathrm{CO}_{2}$ from peak to termination of exercise)].

${ }^{*}: \Delta \mathrm{P}_{\mathrm{ET}} \mathrm{CO}_{2} \geqslant 2 \mathrm{~mm} \mathrm{Hg}$ in $\mathrm{CO}_{2} \mathrm{R}$ and $\Delta \mathrm{P}_{\mathrm{ET}} \mathrm{CO}_{2}<2 \mathrm{~mm} \mathrm{Hg}$ in $\mathrm{CO}_{2} \mathrm{NR}$

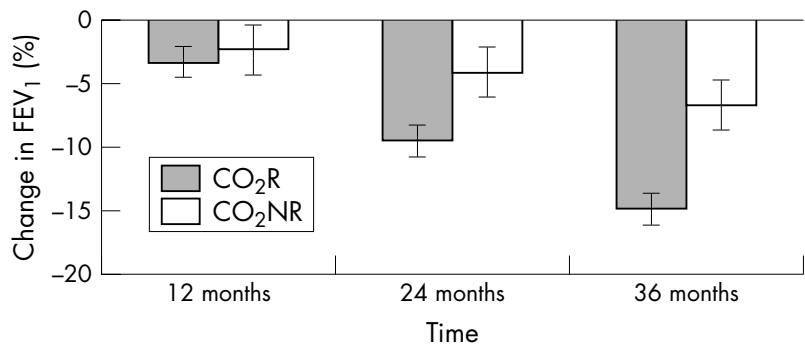

Figure 1 Cumulative decline in $\mathrm{FEV}_{1}$ over time in carbon dioxide retainers $\left(\mathrm{CO}_{2} \mathrm{R}\right)$ and non-retainers $\left(\mathrm{CO}_{2} \mathrm{NR}\right)$. Error bars depict $\mathrm{SD}$.

as the primary continuous variable over time. Statistical significance was assigned when $\mathrm{p}<0.05$. Univariate logistic regression analysis was performed on the following variables: gender, age, minute ventilation at peak exercise, BMI, $\Delta \mathrm{P}_{\mathrm{ET}} \mathrm{CO}_{2}$ as a continuous variable, peak $\dot{\mathrm{V}}_{2}$, pulse oximetry, and initial $\mathrm{FEV}_{1} . \Delta \mathrm{P}_{\mathrm{ET}} \mathrm{CO}_{2}$ was [( change in $\mathrm{P}_{\mathrm{ET}} \mathrm{CO}_{2}$ to peak exercise) + (change in $\mathrm{P}_{\mathrm{ET}} \mathrm{CO}_{2}$ from peak to termination of exercise)]. Using the presented definition of $\mathrm{CO}_{2}$ retention, the parameter $\Delta \mathrm{P}_{\mathrm{ET}} \mathrm{CO}_{2}$ would be expected to be $\geqslant 2 \mathrm{~mm} \mathrm{Hg}$ in this study in the $\mathrm{CO}_{2} \mathrm{R}$ group.

Univariate predictors of moderate statistical significance $(p<0.25)$ were included in the multivariate logistic regression model. Decline in $\mathrm{FEV}_{1}$ over 36 months was the primary outcome, with a decline of greater than $9 \%$ over the three years deemed to be clinically significant. A value of $9 \%$ over three years was chosen as this is the approximate rate of decline in typical subjects with CF. ${ }^{11}$ Computations were made with the SAS statistical program (version 6.12, SAS Institute, Cary, NC). Results were expressed as relative risks with their 95\% confidence intervals (CI).

\section{RESULTS}

The demographic details at baseline are presented in table 1 . The mean age at entry of the subjects in the $\mathrm{CO}_{2} \mathrm{R}$ group was 13.9 years ( $\mathrm{SD} 1.7$ ) and in the $\mathrm{CO}_{2} \mathrm{NR}$ group was 13.6 years (SD 1.8). This difference was not statistically significant. The body mass index was similar in both groups. The mean FEV values at baseline for the two groups were similar $\left(\mathrm{CO}_{2} \mathrm{R} 62 \%\right.$ (range $41-68 \%$ ) and $\mathrm{CO}_{2} \mathrm{NR} 65 \%$ (range 44-69\%)).

At entry in to the study, the mean change in $\mathrm{P}_{\mathrm{ET}} \mathrm{CO}_{2}$ from rest to peak was $6.62 \mathrm{~mm} \mathrm{Hg}$ (SD 1.13) in the $\mathrm{CO}_{2} \mathrm{R}$ group and $2.27 \mathrm{~mm} \mathrm{Hg}$ (SD 1.17) in the $\mathrm{CO}_{2} \mathrm{NR}$ group. With exercise, the $\mathrm{CO}_{2} \mathrm{R}$ and $\mathrm{CO}_{2} \mathrm{NR}$ group reduced their $\mathrm{P}_{\mathrm{ET}} \mathrm{CO}_{2}$ by $2.12 \mathrm{~mm} \mathrm{Hg}$ (SD 0.80 ) and $3.70 \mathrm{~mm} \mathrm{Hg}$ (SD 0.70 ) respectively. The mean $\mathrm{P}_{\mathrm{ET}} \mathrm{CO}_{2}$ at rest in the $\mathrm{CO}_{2} \mathrm{R}$ and $\mathrm{CO}_{2} \mathrm{NR}$ groups were $38.7 \mathrm{~mm} \mathrm{Hg} \mathrm{(1.6)} \mathrm{and} 37.6 \mathrm{~mm} \mathrm{Hg} \mathrm{(2.1)}$ respectively $(\mathrm{p}>0.05)$. In addition, the $\mathrm{CO}_{2} \mathrm{R}$ and $\mathrm{CO}_{2} \mathrm{NR}$ groups increased their tidal volume by $45.7 \%$ (SD 2.2) and $95.4 \%$ (SD 2.8) $(\mathrm{p}<0.05)$ respectively. There was no evidence of desaturation using pulse oximetry in any of the children tested. $\dot{\mathrm{V}}_{\mathrm{E}}$ at peak exercise was significantly less in the $\mathrm{CO}_{2} \mathrm{R}$ group: $61 \mathrm{l} / \mathrm{min}$ (SD 7) versus $78 \mathrm{l} / \mathrm{min}$ (SD 9) in the $\mathrm{CO}_{2} \mathrm{NR}$ group $(\mathrm{p}<0.05)$.

Table 3 Multivariate analysis for decline in $\mathrm{FEV}_{1}$ over 36 months $>9 \%$

\begin{tabular}{lcll}
\hline Parameter & Relative risk & p value & 95\% Cl for RR \\
\hline$\Delta \mathrm{P}_{\mathrm{ET}} \mathrm{CO}_{2}(\mathrm{~mm} \mathrm{Hg})$ & 11.61 & 0.004 & 3.41 to 24.12 \\
$\dot{\mathrm{VO}} \mathrm{F}_{2}$ peak $(\mathrm{ml} / \mathrm{kg} / \mathrm{min})$ & 1.23 & 0.001 & 1.10 to 1.43 \\
$\mathrm{FEV}_{1} \%$ & 1.14 & 0.005 & 1.02 to 1.28 \\
\hline
\end{tabular}




\section{What is already known on this topic}

- Carbon dioxide retention during exercise is uncommon in mild to moderate CF lung disease

- Previous researchers have shown that the ability to deal with increased carbon dioxide is related to factors such as the degree of airflow obstruction and the inherent sensitivity to carbon dioxide

- However, using the current definitions of carbon dioxide retention, the prognostic value of carbon dioxide retention in children with CF has not been evaluated

The decline in $\mathrm{FEV}_{1}$ after l year was $-3.2 \%$ (SD 1.1) in the $\mathrm{CO}_{2} \mathrm{R}$ group and $-2.3 \%(\mathrm{SD} 0.9)(\mathrm{p}>0.05)$ in the $\mathrm{CO}_{2} \mathrm{NR}$ group. The decline in $\mathrm{FEV}_{1}$ in year 2 was $-6.3 \%$ (SD 1.3) in the $\mathrm{CO}_{2} \mathrm{R}$ group and $-1.8 \%$ (SD 1.1) in the $\mathrm{CO}_{2} \mathrm{NR}$ group $(\mathrm{p}<0.05)$. In year 3 , the decline was $-5.3 \%(\mathrm{SD} 1.2)$ and $-2.5 \%$ (SD 1.1) in $\mathrm{FEV}_{1}$ in the $\mathrm{CO}_{2} \mathrm{R}$ and $\mathrm{CO}_{2} \mathrm{NR}$ groups respectively $(\mathrm{p}<0.05)$. Overall, the $\mathrm{FEV}_{1} \%$ predicted declined by $-14.8 \%$ (SD 2.1) in the $\mathrm{CO}_{2} \mathrm{R}$ group and $-6.7 \%$ (SD 1.8) in the $\mathrm{CO}_{2} \mathrm{NR}$ group over three years $(\mathrm{p}<0.01)$. The decline in $\mathrm{FEV}_{1}$ is presented graphically in fig 1 .

Univariate analyses are presented in table 2 . Parameters of moderate statistical significance $(p<0.25)$ were included in the multivariate analysis. The primary outcome measure was the relative risk of a decline in $\mathrm{FEV}_{1}$ of $>9 \%$. The final multivariate analysis results are presented in table 3. The relative risks for the final model were $(95 \%$ CIs in parentheses): $\Delta \mathrm{P}_{\mathrm{ET}} \mathrm{CO}_{2} 11.61$ (3.41 to 24.12), peak $\dot{\mathrm{VO}}_{2} 1.23$ (1.10 to 1.43), initial $\mathrm{FEV}_{1} 1.14$ (1.02 to 1.28 ). We computed $\Delta \mathrm{P}_{\mathrm{ET}} \mathrm{CO}_{2}$ as [(change in $\mathrm{P}_{\mathrm{ET}} \mathrm{CO}_{2}$ to peak exercise) + (change in $\mathrm{P}_{\mathrm{ET}} \mathrm{CO}_{2}$ from peak to termination of exercise)].

\section{DISCUSSION}

This study suggests that children with CF with a similar degree of pulmonary disease as measured by $\mathrm{FEV}_{1}$, if found to have $\mathrm{CO}_{2}$ retention on exercise testing will have a greater decline in $\mathrm{FEV}_{1}$ over a three year period compared to their counterparts who do not retain $\mathrm{CO}_{2}$. In addition to $\mathrm{FEV}_{1}$ and peak aerobic capacity, we have now shown that the presence of $\mathrm{CO}_{2}$ retention during exercise can be an additional prognostic marker of disease progress in cystic fibrosis.

Although $\mathrm{PaCO}_{2}$ values cannot be predicted accurately from $\mathrm{P}_{\mathrm{ET}} \mathrm{CO}_{2}$ values in an individual person, particularly in patients with lung disease or with disorders affecting ventilation/perfusion relationships, measurement of $\mathrm{P}_{\mathrm{ET}} \mathrm{CO}_{2}$ is often valuable for following trends in $\mathrm{PaCO}_{2} \cdot{ }^{15}$ In healthy children carbon dioxide levels rarely increase during exercise and actually fall slightly in vigorous exercise. ${ }^{16}$ Using the definitions for carbon dioxide retention presented earlier, $\Delta \mathrm{P}_{\mathrm{ET}} \mathrm{CO}_{2}$ would be $\geqslant 2 \mathrm{~mm} \mathrm{Hg}$ for $\mathrm{CO}_{2} \mathrm{R}$ and $<2 \mathrm{~mm} \mathrm{Hg}$ for $\mathrm{CO}_{2} \mathrm{NR}$. This study shows that for every $1 \mathrm{~mm} \mathrm{Hg} \Delta \mathrm{P}_{\mathrm{ET}} \mathrm{CO}_{2}$ $\left[\Delta \mathrm{P}_{\mathrm{ET}} \mathrm{CO}_{2}=\right.$ (change in $\mathrm{P}_{\mathrm{ET}} \mathrm{CO}_{2}$ to peak exercise $)+$ (change in $\mathrm{P}_{\mathrm{ET}} \mathrm{CO}_{2}$ from peak to termination of exercise)], there was an almost 12 -fold increase in the risk of the child dropping their $\mathrm{FEV}_{1}$ by $9 \%$ or more over the next three years.

The association of $\mathrm{CO}_{2}$ retention during exercise and poor pulmonary function has been previously reported by Cropp and colleagues.' They also noted a significant correlation between desaturation and $\mathrm{CO}_{2}$ retention at peak work capacity and postulated that $\dot{\mathrm{V}}_{\mathrm{E}}$ was not sufficient to maintain alveolar ventilation. This in combination with excessive dead space ventilation resulted in alveolar hypoventilation. Excessive dead space ventilation in patients with CF was also noted by Godfrey and Mearns, ${ }^{17}$ who suggested

\section{What this study adds}

- Carbon dioxide $\left(\mathrm{CO}_{2}\right)$ retention was defined as a rise of $\geqslant 5 \mathrm{~mm} \mathrm{Hg}$ end tidal $\mathrm{CO}_{2}$ from the first work rate until the peak work rate and a failure to reduce end tidal $\mathrm{CO}_{2}$ after the peak work rate by $3 \mathrm{~mm} \mathrm{Hg}$ by the termination of the exercise

- This study shows that children with CF who were found to have $\mathrm{CO}_{2}$ retention on exercise testing showed a faster rate of decline in $\mathrm{FEV}_{1}$ when compared to those who did not retain $\mathrm{CO}_{2}$

- This additional information may be used to identify those children who may require more intensive therapy to prevent this increased rate in pulmonary decline

that this may be one of the more sensitive indicators of pulmonary dysfunction in cystic fibrosis. Coates and colleagues $^{18}$ showed that the failure to increase tidal volume appropriately, rather than a large physiologic dead space, led to alveolar hypoventilation with consequent exertional hypercapnia.

The $\dot{\mathrm{V}}_{\mathrm{E}}$ at peak exercise was significantly less in our $\mathrm{CO}_{2} \mathrm{R}$ group. This is secondary to the significantly smaller change in tidal volume in this group compared to the $\mathrm{CO}_{2} \mathrm{NR}$ group throughout the exercise test. Compared to healthy subjects, children with severe lung disease have been shown to have an increased $\dot{\mathrm{V}}_{\mathrm{E}}$ per unit work rate. ${ }^{19}$ The reason that some of our cohort who had similar pulmonary function profiles retained $\mathrm{CO}_{2}$ may be due to their poorer $\dot{\mathrm{V}}_{\mathrm{E}}$ response, and/or a higher degree of ventilation/perfusion mismatch in these children.

Nixon et al reported that patients with a $\mathrm{P}_{\mathrm{ET}} \mathrm{CO}_{2}$ $>41 \mathrm{~mm} \mathrm{Hg}$ at peak exercise were more than twice as likely to die within seven years as patients with a $\mathrm{P}_{\mathrm{ET}} \mathrm{CO}_{2}$ $\leqslant 36 \mathrm{~mm} \mathrm{Hg}^{7}$ Coates et al have shown that the ventilatory response to a $\mathrm{CO}_{2}$ stimulus in children with $\mathrm{CF}$ is the combined result of the degree of chronic airflow obstruction and an inherent sensitivity to the $\mathrm{CO}_{2}$ drive to breathe. ${ }^{20}$ Therefore, the different handling techniques of a $\mathrm{CO}_{2}$ stimulus may be one cause of exertional hypercapnia.

The $\mathrm{CO}_{2} \mathrm{R}$ group showed an increasingly significant decline in $\mathrm{FEV}_{1}$ over three years. Though the $\mathrm{CO}_{2} \mathrm{R}$ group had a slightly lower $\mathrm{FEV}_{1}$ profile $(62.3 \%$, range $41-68 \%$ ) compared to the $\mathrm{CO}_{2} \mathrm{NR}$ group $(64.7 \%$, range $44-69 \%)$ at the commencement of the study, the difference was not great enough to explain the more rapid decline in the $\mathrm{CO}_{2} \mathrm{R}$ group. By the third year there was a decline of $-5.3 \%$ (SD 1.2) and $-2.5 \%$ ( $\mathrm{SD}$ 1.1) in the $\mathrm{CO}_{2} \mathrm{R}$ and $\mathrm{CO}_{2} \mathrm{NR}$ groups respectively. The average decline in $\mathrm{FEV}_{1}$ per annum was $-4.9 \%$ in the $\mathrm{CO}_{2} \mathrm{R}$ group compared with $-2.3 \%$ in the $\mathrm{CO}_{2} \mathrm{NR}$ group. This estimate for the $\mathrm{CO}_{2} \mathrm{NR}$ group is similar to that reported from Toronto for a combined sample of children and adults with CF. ${ }^{1121}$

In summary, children with CF who were found to have $\mathrm{CO}_{2}$ retention on exercise testing showed a faster rate of decline in $\mathrm{FEV}_{1}$ when compared to those who did not retain $\mathrm{CO}_{2}$. This additional information may be used to identify those children who may require more intensive therapy to prevent this increased rate in pulmonary decline.

\section{Authors' affiliations}

S M Javadpour, H Selvadurai, D L Wilkes, J Schneiderman-Walker,

A L Coates, Department of Respiratory Medicine, The Hospital for Sick Children, Toronto, Ontario, Canada

Competing interests: none declared 


\section{REFERENCES}

1 Huang NN, Schidlow DV, Szatrowski TH, et al. Clinical features, survival rate, and prognostic factors in young adults with cystic fibrosis. Am J Med 1987;82:871-9.

2 Kerem E, Reisman J, Corey $M$, et al. Prediction of mortality in patients with cystic fibrosis. N Engl J Med 1992;326:1187-91.

3 Wall MA, LaGesse PC, Istvan JA. The "worth" of routine spirometry in a cystic fibrosis clinic. Pediatr Pulmonol 1998;25:231-7.

4 Taussig LM, Kattwinkel J, Friedewald WT, et al. A new prognostic score and clinical evaluation system for cystic fibrosis. J Pediatr 1973;82:380-90.

5 Tablan OC, Chorba TL, Schidlow DV, et al. Pseudomonas cepacia colonization in patients with cystic fibrosis: risk factors and clinical outcome. J Pediatr 1985;107:382-7

6 Corey M, McLaughlin FJ, Williams M, et al. A comparison of survival, growth, and pulmonary function in patients with cystic fibrosis in Boston and Toronto. J Clin Epidemiol 1988:41:583-91.

7 Nixon PA, Orenstein DM, Kelsey SF, et al. The prognostic value of exercise testing in patients with cystic fibrosis. N Engl J Med 1992;327:1785-8.

8 Moorcroft AJ, Dodd ME, Webb AK. Exercise testing and prognosis in adult cystic fibrosis. Thorax 1997;52:291-3.

9 Cropp GJ, Pullano TP, Cerny FJ, et al. Exercise tolerance and cardiorespiratory adjustments at peak work capacity in cystic fibrosis. Am Rev Respir Dis 1982;126:211-16.

10 American Thoracic Society. Standardization of spirometry-1987 update. Official statement of American Thoracic Society. Respir Care 1987;32:1039-60.
11 Corey M, Levison H, Crozier D. Five- to seven-year course of pulmonary function in cystic fibrosis. Am Rev Respir Dis 1976;114:1085-92.

12 American Thoracic Society. Standardization of spirometry, 1994 update. American Thoracic Society. Am J Respir Crit Care Med 1995;152:1 107-36.

13 Godfrey S, Davies CT, Wozniak E, et al. Cardio-respiratory response to exercise in normal children. Clin Sci 1971;40:419-31.

14 Jones NL. Clinical exercise testing. Philadelphia: WH Saunders, 1997.

15 Wasserman KHJ, Daryl S, Hansen J. Pathophysiology of disorders limiting exercise. In: Wasserman KHJ, ed. Principles of exercise testing and interpretation. Pennsylvania, PA: Lea \& Febiger, 1994.

16 Eriksson BO, Grimby G, Saltin B. Cardiac output and arterial blood gases during exercise in pubertal boys. J Appl Physiol 1971;31:348-52.

17 Godfrey S, Mearns M. Pulmonary function and response to exercise in cystic fibrosis. Arch Dis Child 1971;46:144-51

18 Coates AL, Canny G, Zinman R, et al. The effects of chronic airflow limitation, increased dead space, and the pattern of ventilation on gas exchange during maximal exercise in advanced cystic fibrosis. Am Rev Respir Dis 1988; 138:1524-31.

19 Cerny FJ, Pullano TP, Cropp GJ. Cardiorespiratory adaptations to exercise in cystic fibrosis. Am Rev Respir Dis 1982;126:217-20.

20 Coates AL, Desmond KJ, Milic-Emili J, et al. Ventilation, respiratory center output, and contribution of the rib cage and abdominal components to ventilation during $\mathrm{CO} 2$ rebreathing in children with cystic fibrosis. Am Rev Respir Dis 1981;124:526-30.

21 Corey $M$, Edwards L, Levison $\mathrm{H}$, et al. Longitudinal analysis of pulmonary function decline in patients with cystic fibrosis. J Pediatr 1997; 131:809-14.

\section{bmjupdates+}

bmjupdates+ is a unique and free alerting service, designed to keep you up to date with the medical literature that is truly important to your practice.

bmjupdates+ will alert you to important new research and will provide you with the best new evidence concerning important advances in health care, tailored to your medical interests and time demands.

Where does the information come from?

bmjupdates+ applies an expert critical appraisal filter to over 100 top medical journals A panel of over 2000 physicians find the few 'must read' studies for each area of clinical interest

Sign up to receive your tailored email alerts, searching access and more...

www.bmjupdates.com 